\title{
Religion, Intersectionality, and Epistemic Habits of Academic Feminism. Perspectives from Global Feminist Theology
}

\author{
Elina Vuola 1*
}

Published: October 30, 2017

\begin{abstract}
This article pays critical attention to the ways in which academic feminism has regarded religion. Issues related to religion and gender have by and large either been ignored or treated quite stereotypically. I have called this phenomenon a simultaneous under- and overestimation of religion. The phenomenon is not global. Feminists of the global south tend to pay much more and more multi-faceted attention to religion than scholars from the global north. I will illustrate this problem through a close reading of intersectionality in feminist research in religion, especially feminist theology. My argument - which can be supported by evidence from historical records - is that what has been called intersectionality since Kimberlé Crenshaw, has in fact been explicitly present in early feminist theology (1970s-). The reason why feminist liberation theologians stressed the interstructuring of gender, class, and race/ethnicity lies in their practical and theoretical cooperation with liberation and feminist theologians from the global south, for example through the Ecumenical Association of Third World Theologians (EATWOT). My article is a critical re-reading of the history of feminist theorizing from the perspective of religious feminists, academic feminist theologians and liberation theologians from both the global north and south (including black and womanist theologians from the USA, Latin America and Africa). My aim is to correct a long-held understanding of the history of feminist theorizing as purely "secular".
\end{abstract}

Keywords: feminist theology, liberation theology, feminist theory, religion, intersectionality

\section{INTRODUCTION}

In my article 1 I pay critical attention to the ways in which academic feminism has regarded religion. I argue that interdisciplinarity in feminist studies is not always practised or is practised selectively. I suggest that research on the study of religion is seldom substantially engaged with in the field of feminist studies or considered as part of feminist theory proper. Therefore, I am articulating an epistemic habit of exclusion as well as calling for greater and deeper interdisciplinarity in feminist studies.

My intention is to engage in a critical re-reading of the history of feminist theory from the perspective of religious feminism. This includes academic feminist theology, and liberation theology from both the global north and south, including black and womanist theologies from the United States, Latin America, and Africa. I wish to shed light on aspects of feminist thinking that have remained in the shadows, because of a persistent misrepresentation of the history of the feminist movement and of a representation of feminist theorising as purely secular. In this, I join feminist historians, who have stressed and documented the importance of religion for $19^{\text {th }}$ and early $20^{\text {th }}$ century feminists as well as for more contemporary feminists (e.g. Braude 2001; contributors to Braude, ed. 2004; Hammar 2010; Kinnunen 2014).

In order to make my argument about the exclusion of religion more concrete, I will analyse how the idea of intersectionality has been employed in feminist theology much earlier than in other fields of feminist studies. ${ }^{2}$

\footnotetext{
${ }^{1}$ This article has been written within the research project Embodied Religion. Changing Meanings of Body and Gender in Contemporary Forms of Religious Identity in Finland, directed by myself and funded by the Academy of Finland (2013-17).

${ }^{2}$ The only other field with such an early direct relationship with feminist organising and theorising in the south is probably feminist development studies (Vuola 2016: 317).
} 
Obviously, black feminism in the United States is the most important historical background for the development of such an intersectional feminism which looks at gender in relation to race and class. However, my argument, which can be sustained through historical records, is that what is called intersectionality since Kimberle Crenshaw coined the term in 1989, has been explicitly present in feminist theology since the early 1970s. This included black feminist theologians who started to call their work womanist theology, the term 'womanist' inspired by Alice Walker (1983). Even in the history of black feminism, the importance of religion and theology has, I argue, often been ignored.

Since the early 1970s, feminist theologians stressed the significance of the interstructuring of gender, class, colonialism, race, and ethnicity, to emphasise their practical and theoretical cooperation with liberation and feminist theologians from the global south. They did not use the term 'intersectionality', but they conceptually meant the same. I emphasise that what feminist theologians did was to theorise the experiences of multiple oppressions. They paid attention to the intersecting categories of gender, class and race and addressed colonialism, north-south relations and worked within a global perspective in their theorising and writing. This resulted in a body of work that has yet to be fully explored. Further, I argue that the work of feminist theologians should be considered as part of the intellectual history of academic feminism, as it forms a body of work that shows us the need to analyse power and oppression beyond the singularity of identity categories.

Finally, I present a short history of the global ecumenical and interfaith processes of dialogue between religious feminists and feminist theologians as one not widely considered locus of history of feminism, which also was of importance for the development of feminist theology. These connections between women from different parts of the world can be understood as a parallel development to their secular counterpart within the United Nations. The extent to which the two processes, the secular and the religious, overlapped and how, is an issue to be explored in future research. Churches and religious institutions form concrete transnational networks with both local and global constituencies and their own support and financing systems. Religious institutions and communities have access to all levels of society in all parts of the world. To overlook their importance in the development of women's transnational dialogue and support systems is to overlook an important and well-established part of global feminism.

Feminist theorists of the global south tend to pay much more attention to religion and in a more multi-faceted way than gender scholars from the global north (e.g., Narayan 2000). The interplay of colonialism, religion, and gender, both historically and currently, has made it necessary for feminists in colonialised regions to be more sensitive to religion. For example, they pay attention to the ways religion has historically played a role in portraying women in colonialised regions as subordinate and in need of Western civilising effects (e.g., Ahmed 1992). At the same time, their attention towards religion is not only critical or negative: different religious traditions hold also empowering aspects for women. ${ }^{3}$

I will demonstrate how feminists from different faith traditions used ecumenical and interfaith networks that had been well-established at least since the Second World War as a context for developing feminist theologies. These were created with the aim of forming a critique of religion that would be attentive not only to gender and women's position in different religious traditions, but also to colonialism, class, race, and ethnicity. ${ }^{4}$

My emphasis in this article is historical: through tracing the development of global feminist liberation theology, I bring religion to the centre of feminist historiography. Thus, my article is not only an example of a critical rereading of the history of feminist theorising, but also a critique of the epistemic habit of excluding feminist theology in academic feminism. Because of my emphasis on early feminist theology, it is beyond the scope of this article to analyse if and how the concept of intersectionality is included in contemporary feminist theology. ${ }^{5}$

Nuanced analyses of gender and religion derive from a variety of perspectives and cultural contexts in religious studies, anthropology, theology, and sociology of religion. As I argue throughout this article, a lack of substantial dialogue with those fields of study results in a somewhat outdated understanding of what is considered feminist studies proper. The result is both a too narrow presentation of feminist theory in general because of the exclusion of the study of religion, and a too-thin and even misconstrued understanding of the interplay between religion and gender.

\footnotetext{
${ }^{3}$ However, I have been critical of this oblivion of the more positive aspects of religion in the context of Latin America. The Catholic Church as a socially and culturally powerful institution is strongly criticised —and often rightly so-by feminist activists and scholars of the region, but often without an adequate understanding of the multiple meanings Catholicism holds for women (Vuola 2006: 142-148; Vuola 2009: 221-227; Vuola 2012b).

${ }^{4}$ I make this point in Vuola 2016, but develop it here further and in more detail.

${ }^{5}$ Analysing contemporary feminist theology and its development since the 1980 s could be the subject of another article. Here my point is explicitly historical in order to trace some of the more invisible sources of feminist thinking. In the feminist theology of the 1970s and 1980s, much like in other fields of research, the focus was on women. This has changed in more recent feminist theology, but since my focus is in the early phase, I am not discussing the problems which later feminist thinking has seen in the identification of 'gender' with 'women'.
} 
Following Clare Hemmings' (2011) insistence on paying attention to the stories that are told and mechanisms of exclusion in the historical record of academic feminism, I wish to highlight an excluded body of work: the meaning and importance of religion, and more specifically, of global feminist theology. I consider feminist theology to be early feminist theorising which is both intersectional and international in its approach and scope.

\section{RELIGION AND THE NARRATIVES OF ACADEMIC FEMINISM}

The phenomenon of the treatment of religion in feminist theory could be described as a simultaneous underand over-estimation of religion. In the former case, the under-estimation has also been called feminist blindness to the importance of religion (for women), especially in its positive aspects, whereas the latter case points to a religion-as-a-lens type of theorising, in which religion is seen as the main explanatory factor of women's lives in a given culture, mainly in negative terms: religion as the root of women's oppression (Vuola 2012a: 497; Vuola 2015a: 17). According to Ursula King:

At present there still obtains a harmful 'double blindness' in which most contemporary gender studies, whether in the humanities, social sciences, or natural sciences, remain extraordinarily 'religion blind', whereas far too many studies in religion are still quite 'gender blind'. (King 2005: 3297)

There are several reasons why such a simplistic view of religion is so prevalent in feminist studies. One of the reasons is the influence of the so-called secularisation thesis; although it is questioned today, it has influenced the social sciences, including much of feminist theorising. Secularisation was seen as a universal and inevitable development, even though case studies have proven the opposite (Casanova 1994). Only lately, with the resurgence of religion in Western societies, both as a renewed interest in spirituality and as a result of religion-based violence and terrorism, social scientists have acknowledged that the prediction was false or at least overestimated. The obvious and well-documented sexism of different religious traditions is another reason for a polarised view of religion in feminist studies. What both approaches lack is the acknowledgement of the long history of religious feminism and the related theoretical work, known as feminist theology particularly in the Anglo-American world. ${ }^{6}$ The contemporary post-secular approach in gender studies (e.g., Braidotti 2008) is an attempt to address this neglect of religion, but without an in-depth discussion and dialogue with the substantial and diverse body of work of feminist scholars of religion.

In the late 1990s, the Swedish historian Inger Hammar (1998) pointed out that feminist historians have too often been 'religion blind', not only in relation to women, but also particularly in the case of early feminists. She later wrote:

Since it has been long assumed that the emancipation of women and secularization went hand in hand, research into the history of Swedish women has spent little time in tracing the strongly Christian tone of the feminist movement. (...) In doing so, historians have overlooked the contradictions inherent in the fact that from the middle of the nineteenth century, the women who first initiated and then drove forward the emancipation debate were ideologically anchored in a context that has been labelled as hostile to emancipation. (Hammar 2010: 57-58)

Similarly, in the American context, Catherine Brekus writes: "At the same time as American religious historians have failed to write about women, many American women's historians have failed to consider religion" (Brekus 2007: 24 , emphasis in original). She claims that women's historians have been especially blind to the continuing power of religion in modern America, ' (...) as if women never went to churches, synagogues, or mosques. (...) When they [women's historians] have written about the feminist movement of the 1960s and 1970s, they have simply assumed that it was secular in nature' (Brekus 2007: 27). She goes on to suggest the effects on women's identities by saying:

Ironically, women's historians have prided themselves on recovering the stories of forgotten women, yet whether intentionally or not, they have engaged in their own kind of forgetting. Many have virtually erased women's religious identities (Brekus 2007: 26).

In 2002, historian Ann Braude convened a conference at the Harvard Divinity School in which I participated; it was a gathering of the first generation of feminist theologians and religious leaders from different faith traditions in the United States. In the introduction to the proceedings of the conference, Ann Braude wrote:

\footnotetext{
${ }^{6}$ The term feminist theology is problematic for many reasons beyond Christianity. It is either not used at all, or, as in the case of Islam, most feminist scholars are legal scholars or social scientists, not 'theologians' even when they write primarily on issues related to religion.
} 
As a group, religious feminists have worked over the last forty years to lift the religious women of the ages from obscurity, to acknowledge their roles in scripture, ministry, theology, worship, teaching, and devotion. Imagining and constructing non-sexist religious models for the women and men of the future, they have critiqued the conditions that fostered women's exclusion, so that those conditions can be changed. What a dreadful irony it would be, if their own history, the story of religion's interaction with feminism, fell out of the narrative, just at the moment when the history of the second wave is being written (...). (Braude 2004: 3)

Braude refers to the way in which the historiography of second wave feminism in the United States tends to leave out the voice, thoughts, and activities of religious feminists and academic feminist theologians. This epistemic gesture, for her, as a historian of religion, is 'inaccurate, a misreading of America's past' (Braude 2004: 2).

To tell the story of second-wave feminism and feminist theory in purely secular terms is problematic as it makes feminist scholarship on religion and religious feminism invisible. In another text, Braude (2001: xxii-xxiv) provides two broad arguments for why the inclusion of religion within the historical assessment of feminism as an ideology and as a political movement in both the $19^{\text {th }}$ and $20^{\text {th }}$ centuries is important. First, it can help dispel the idea that religion and feminism are opposing forces. This is an assumption shared by both conservative religious sectors and feminism, and based on misconceptions about the relationship between religion and feminism (ibid.: xxii). Second, including religion in analyses of the history of feminism is necessary to provide an accurate assessment of the movement's impact in a given society. Part of this impact happened in different religious traditions. Many religious feminists chose to maintain ties to their communities of faith while participating in the struggle for women's rights (including as founding members of the National Organization of Women in the United States). Besides their work in secular contexts, these feminists also held that religion was often an important aspect of their activity (ibid.: xxiii). I concur with Braude regarding her hope to "contribute to the continuing challenge of incorporating feminism into religious history and religion into the history of feminism' (ibid.: xxiv).

A recent example of the neglect of religion in feminist theory and historiography is particularly illuminative because of its explicit goal to critically re-read the history of feminist theory as an excluding endeavour. Clare Hemmings' critique of the dominant narratives of Anglo-American feminist theory as a narrative of progress (loss and return) and her insistence on alternative histories and narratives (Hemmings 2005 and 2011) is compelling. Hemmings (2005) identifies, describes, and analyses the dominant stories that academics tell about the development of Western, second-wave feminist theory. She suggests that despite a rhetorical insistence on multiple feminisms, Western feminist trajectories emerge as startlingly singular. In her later work (2011), she emphasises the need for alternative stories that 'highlight what has been left out and endeavour to reinsert those omissions into the historical record' (2011: 13).

Despite Hemmings' insistence on correcting the omissions, she does not address the vast amount of scholarship that carefully documents the (sometimes intimate) relationship between religion and feminism in different parts of the world. It is not only the representation of the development of feminist theorising in terms of waves (with their corresponding decades), which is problematic, as Hemmings points out. The problem is also the omission of vast waters that may have their own 'waves' of feminist theorising. It should be noted that Hemmings' work is based on an analysis of a certain body of work. Hemmings' sources are those that by and large render religion invisible. Thus, it is telling that religion is not part of this material: not paying attention to religion is indeed a habit of feminist scholarship, which Hemmings however reproduces in her own work.

Hemmings' critique of the dominant narratives and their corresponding shifts and waves according to decades as well as her notion that this tale is primarily Western and Anglo-American is, in my view, brilliant. However, her omission of religion and the global feminist study of religion is revealing of the narrowly secular and Western framework of what is conceived as feminist theory.

In order to bring the history of feminist theology at the heart of feminist theory and make my argument about the importance of inclusion of religion more concrete, I will next analyse how the idea of intersectionality has been employed in feminist theology earlier than the history of intersectionality acknowledges. I start with a more general discussion of intersectionality and the study of religion.

\section{INTERSECTIONALITY AND RELIGION}

Intersectionality is not a unified theory or approach. It is not a grand new theory, but rather one way of conceptualising a central theoretical development in recent feminist theory. There are different ways of understanding and using the concept of intersectionality in contemporary feminist theory. There are various ways of understanding and naming the object of intersectional analysis: it can be asymmetries of power structure, identity (formation), difference, and social division (Lykke 2003: 48 and 2005; Nash 2008; Yuval-Davis 2006). Sometimes these differences are related to disciplinary differences, such as philosophy and sociology, resulting in differences 
of focus. What all the approaches have in common is the analysis of mutually constructing systems of power through which differences such as ethnicity, race and gender are understood not only as forms of identity (positive and critical) but as categories penetrated by social, cultural and political power.

Even theories of intersectionality that explicitly pay (self-) critical attention to the blind spots of feminist theory and the myriad differences among women, have by and large not been able to see religion as an important factor in (marginalised) women's lives. In fact, most theorists of intersectionality do not even mention religion (besides Crenshaw, and other widely quoted scholars such as Davis 2008; Ludvig 2006; Lykke 2005; McCall 2005; Nash 2008). Those scholars who at least mention religion, even if on a rather general level, as a 'difference' or 'category' to be considered tend to be those who think within postcolonial feminism. For example, Avtar Brah and Ann Phoenix ask how do we challenge simplistic binaries which posit secularism and fundamentalism as mutually exclusive polar opposites?' (Brah et al. 2004: 83) and even take the title of their article 'Ain't I a Woman?' from Sojourner Truth, the black slave who in her 1851 speech challenged both sexism and racism on the basis of her God-given equality. Truth's speech is yet another example of the long history of interaction between religion and feminism. Also, Nira Yuval-Davis (2006: 205) mentions religion as one of the social divisions to be applied especially in international human rights discourses and practices.

Through intersectionality, a process of diversification of central concepts such as gender and women and the inclusion of differences between women has happened, largely through the inclusion of race, class, ethnicity, and sexual orientation into feminist theory. ${ }^{7}$ Intersectionality is a broad way of theorising gender in relation to these other differences and constructions of identity and selfhood, showing how a variety of oppressive structures such as sexism and racism - influences these. Religion has rarely been mentioned among these differences, and even less so as an empowering factor in spite of the insistence of religious feminists from different parts of the world.

Several feminist scholars of religion have pointed out this omission. For example, according to Elizabeth Castelli:

(. . .) if 'women' has long been recognized as too abstract a category to be useful for analysis, religion has rarely been included in the litany of qualifiers (race, class, culture, ethnicity/nationality, sexuality) by which 'women' becomes an evermore marked and differentiated category. Yet, feminist scholars who intervene in the academic study of religion have often drawn attention to the complicated role that religion has played in identity formations, social relations, and power structures. 'Religion' as a category often cuts across other categories by which identities are framed (gender, race, class, etc.), and it often complicates these other categories rather than simply reinscribing them. (2001: 4-5)

Anthropologist Saba Mahmood (2005), who has done fieldwork among conservative Muslim women in Egypt, expresses a similar view:

Over the last two decades, a key question has occupied many feminist theorists: how should issues of historical and cultural specificity inform both the analytics and the politics of any feminist project? While this question has led to serious attempts at integrating issues of sexual, racial, class and national difference with feminist theory, questions regarding religious difference have remained relatively unexplored. (Mahmood 2005: 1)

Deeper elaborations on how exactly religion(s) could and should be understood and applied in intersectional analyses are nevertheless pretty much lacking. The Swedish theologian Erica Appelros is one of the few who argues that religion is often a relevant dimension in intersectional analyses. She introduces the concept of 'religious proximity' as a tool to facilitate a more complex analysis of situations where a religious dimension interacts with other dimensions (Appelros 2005). Like Appelros, I have analysed religion as a possible category in intersectional analysis, after taking critical distance from some of the ways intersectionality has been theorised (Vuola 2012a and 2015b). ${ }^{8}$

Leslie McCall makes a distinction between different methodological approaches in intersectional analysis. Even though she does not mention religion, I find her intra-categorical approach (McCall 2005) a possible analytical tool to understand religion in the context of intersectional theorizing better. Religion and religious practices should not

\footnotetext{
${ }^{7}$ Recently also able-bodiedness, trans and cis, and queer perspectives.

${ }^{8}$ In Vuola 2012a, I analyse intersectionality in two contexts, Latin American studies and study of religion, and take an example of the cross-reference of these from my ethnographic research among Costa Rican Catholic women. The article has been translated and published also in Portuguese as 'Interseccionalidade na América Latina? As possibilidades da análise interseccional nos estudos latino-americanos de religião.' Estudos feministas e religião: tendências e debates. Eds. Sandra Duarte de Souza \& Naira Pinheiro dos Santos. Prisma: Curitiba 2014, 15-38.
} 
be interpreted only in relation to secular societies and their norms. Gender asymmetries legitimised by religion and practices within religions should also be seen as important objects of analysis. Both should be done simultaneously (Vuola 2012a: 142-143).

\section{FEMINIST THEOLOGY AND INTERSECTIONALITY}

The idea and experiences of simultaneous and multiple oppressive structures is obviously much older than feminist theology and intersectionality, and had been expressed by feminists of racial minorities in the United States and elsewhere. What Crenshaw did was to introduce the problem under a single term into contemporary feminist theory. My point is that what is largely represented by the term as presented by Crenshaw was originally theorised by feminist theologians, without any crucial difference to Crenshaw's understanding of the term, except that feminist theologians had religion at the centre of their scholarly interest. Thus, there is both similarity and difference to Crenshaw's view.

Rather than downplaying the importance and originality of Crenshaw, I wish to point to two interrelated problems. First, religion as a complex phenomenon has been downplayed in feminist theory, as I have argued throughout the article. Second, fields that do have religion as their focus, such as feminist theology and more broadly, feminist studies of religion, have not been recognised as key fields of feminist theorising. If they were acknowledged as key fields, it would most likely be commonly understood that intersectionality was first explicitly theorised within the feminist study of religion.

For example, the Catholic feminist theologian Rosemary Radford Ruether, possibly the most influential feminist theologian of all time, wrote already in 1975:

(...) any women's movement which is only concerned about sexism and no other form of oppression, must remain a women's movement of the white upper class, for it is only this group of women whose only problem is the problem of being women, since, in every other way, they belong to the ruling class. (...) Thus it seems to me essential that the women's movement reach out and include in its struggle the interstructuring of sexism with all other kinds of oppression, and recognize a pluralism of women's movements (...). (Ruether 1975: 125, emphasis in the original)

Feminist theology has been and is interreligious, ecumenical, and global, which I will illustrate in the next section. This has meant that the voices and critiques of women from the global south - Asia, Africa and Latin America - were included in feminist theology quite early. The ecumenical and interfaith organisations offered a concrete network of collaboration and mutual critique among feminist theologians from different parts of the world in the 1960s and 1970s (Vuola 2016: 316). Feminist theologians from the south have emphasised community, including the religious community, issues of poverty, and the variations of local forms of patriarchal attitudes. The legacy and influence of colonialism is intimately tied to all kinds of feminist analyses from the global south, including theology. The insights of postcolonial theory bear a greater weight for scholars from colonialized contexts (e.g., see contributors to Donaldson et al., eds. 2002). According to Ruether, in the US context:

(...) racism and sexism have been closely interrelated historically, especially in the American South, but they have not been exactly parallel. Rather, we should recognize them as interstructural elements of oppression within the overarching system of white male domination. But this interstructuring of oppression by sex, race, and also class, creates intermediate tensions and alienations - between white women and black women, between black men and white women, and even between black men and black women. (Ruether 1975: 116).

Earlier, Ruether had taken different forms of oppression as her explicit starting point (Ruether 1972). In addition to sexism and racism, Christian antisemitism and ecological issues have since been the focus of her work. In her books and articles, she analyses gender, class issues, racism, colonialism, antisemitism, and ecology as interconnected forms of oppression and marginalization (see also Ruether 1982: 52-54).

At the aforementioned conference at Harvard, Ruether described how her feminism grew out of her experiences as a white woman in the civil rights movement in the mid-1960s:

For me, those early experiences in the civil rights movement (...) were very formative in grounding my understanding of feminist theology as situated in an interconnected class, race, and gender analysis. (...) I think it has been largely misinterpreted or forgotten by feminists in the academy and theological schools who began their work in the 1980s or 1990s (...). This scenario violates and indeed erases my own experience and that of a cohort of other feminist theologians (such as Letty Russell and Beverley Harrison) who began our work in the late 1960s and early 1970s. (Ruether in Braude, ed. 2004: 73-74) 
Interestingly, in this she is part of a long history of American feminism, which started in the late $19^{\text {th }}$ century as part of the abolitionist movement. Both white and black women used religion as a base to argue against racism and sexism. In the two quotations, Ruether uses the terms interstructuring, interconnectedness, and interrelatedness of different forms of oppression; this should be recognised as a form of intersectional thinking before the term itself was coined. In other words, if we are interested in how the term came about in the context of American feminism, we should remember the intellectual legacy of early feminist theologians such as Ruether, in addition to influential black feminist thinkers.

In the same essay, Ruether also points out that 'it was not race, class and global awareness, but gender analysis that was not welcome in the circles that had mentored me in critical consciousness' (ibid.: 76). She refers here to the birth of black and Third World liberation theologies, to which I will turn later in the article. Similar quotations are found in Ruether's writings on the interstructuring and interrelatedness of different forms of experienced marginalisation and oppression. In fact, I would argue ${ }^{9}$ that the understanding of what is today called intersectionality, namely the overlapping and interrelatedness of different categories, is the most important overall theme in her thinking.

Other early feminist theologians share Ruether's understanding. For example, in one of the very first collections of feminist theology from 1979, ${ }^{10}$ the editors, Carol Christ and Judith Plaskow, say: ' (...) this dualistic pattern has been adapted to the oppression of other groups, including Jews and blacks, who, like women, are seen as more carnal and irrational than the dominant men' (Christ and Plaskow, eds. 1979: 5). It is noteworthy that this collection, possibly the very first in feminist theology, includes articles by Christian, Jewish, and Goddess (feminist postChristian and post-Jewish spirituality) theologians, or, in the case of the latter, thealogians, as they later called themselves (theos=god, thea $=$ goddess, Gr.).

Another first-generation feminist theologian, Elisabeth Schüssler Fiorenza, writes:

In the 1970s, so another story goes, White middle-class western wo/men ${ }^{11}$ had a monopoly on feminism and articulated feminist theology in the interests of elite White wo/men only, whereas in the 1980s wo/men of color assumed power and unseated White feminist theology with womanist, mujerista, or Third World wo/men's theology. (...) such progressivist replacement tales are not only misleading and prejudicial, but also do not square with the actual historical situation of feminism in the academy and in religious institutions (...) nor do they square with the theoretical conceptualization and intention of most feminist work in the 1970s. (...) such a progressivist conceptualization of feminist history overlooks the fact that the wo/men's liberation movement emerged in the context of the free speech, civil rights, Third/Fourth World liberation, and the antiwar movements of the 1960s. (Fiorenza in Braude, ed. 2004: 137-138).

Interestingly, Fiorenza's critique of the narrative of the history of feminist theology entails a similar critique of progress as Clare Hemmings' critique of secular feminist theory, discussed earlier.

Womanist theology (black feminist theology, see e.g., Cannon 1988, Grant 1989) and mujerista theology (Latina/Hispanic feminist theology, see e.g., Isasi-Díaz and Tarango 1988) emerged as critical reactions to black theology in both the United States and southern Africa, Latin American liberation theology and white feminist theology. Womanist theologians built on the already existing analysis of the interstructuring of race and gender in their critique of the sexism in black theology and liberation theology of their time. Womanist theologians differed from other feminist theologians in their more positive assessment of the Christian tradition: the black churches and African-American spirituality, as expressed for example in negro spirituals, were important and positive sources of community, identity, and hope during slavery and afterwards. In this sense, it is no surprise that some of the most important black leaders in both the United States and South Africa have been priests, such as Dr. Martin Luther King, Jr. and Desmond Tutu. ${ }^{12}$

However, as Kwok Pui-lan reminds us, it is incorrect to present the resurgence of different forms of feminist theology as a lineage from white feminist theology to its 'derivations'. According to her:

When describing this diverse and multifaceted theological movement [feminist theology], scholars tend to give primacy to the contributions of women of European descent. They are considered 'fore-mothers' who have laid the foundation of the discipline, upon which others can build. The assumption is that

\footnotetext{
${ }^{9}$ I wrote my Master's thesis in the mid-1980s on Ruether's thinking and have read practically all her publications ever since. My dissertation (Vuola 2002) deals with the differences and similarities between feminist theology and Latin American liberation theology.

${ }^{10}$ A European volume of feminist theology came out the same year. See Halkes and Buddingh (eds.) 1979.

11 Through this term (wo/men) Fiorenza, at some point, started to refer not only to women but also to disadvantaged men.

${ }^{12} \mathrm{I}$ am not aware of such research which would look at the role of religion, especially in its positive aspects, for the development of American black feminism, which is also the intellectual background of thinkers such as Crenshaw.
} 
white feminist theology appeared first on the scene, and its emergence made possible the development of black women's theology, Hispanic women's theology and various Third World feminist theologies. Such a reading is not only Eurocentric, it also mystifies and obscures the profoundly intercultural character of feminist theology. I want to argue that feminist theology is not only multicultural, rooted in multiple communities and cultural contexts, but is also intercultural because these different cultures are not isolated but intertwined with one another as a result of colonialism, slavery, and cultural hegemony of the West. (Kwok 2002: 24-25)

According to Kwok, the different forms of feminist theology around the world have stressed the differences among women, and intense debates around the politics of identity have taken place. She notes:

Although these discourses [on difference] have their own history and institutional sites, they are not isolated but often overlap with one another. The first discourse emerged in the late 1970s and early 1980s when (...) womanist theologians spoke about the 'multiple oppression' or 'triple jeopardy' of black women (Kwok 2002, 30).

\section{GLOBAL LIBERATION THEOLOGY, THE ECUMENICAL MOVEMENT AND FEMINISM}

In this section, I will look at some institutional sites, mentioned above by Kwok, and the related specific history of feminist theology, which may help us understand how the early inclusion of different forms of oppression came about in feminist theology.

The early emphasis of feminist theologians from both the global north and the global south on the interstructuring systems of power and oppression in relation to religion was an outcome of their collaboration with a global theological movement that could be broadly called liberation theology. In the narrow sense, the term refers to Latin American liberation theology (teologia de la liberación); in the broader sense, it refers to different kinds of contextualised theologies aimed at an analysis of the interplay of religion with sexism, racism and colonialism. In the 1980s, there were already Asian and African liberation theologies, black theology in both South Africa and the United States, and feminist theologies in all those contexts.

Liberation theology, born in the 1970s, was in the broad sense a reaction to the role which especially Christianity had held in the areas colonised by Europe, and its long-standing effects such as chronic poverty. ${ }^{13}$ What is relevant here for my argument about feminist theology is the existence of feminist liberation theology (see, for example, Fiorenza 1975), which has had multiple expressions and forms. First-generation North American feminist theologians, such as Rosemary Ruether and Elizabeth Schüssler Fiorenza, in fact named their theology feminist liberation theology. The very term points to the broader agenda of the interstructuring of different forms of oppression and the necessity of feminist analysis of all of them.

Feminist liberation theologians were practically and conceptually linked to liberation theology, which was a theoretical, practical and political movement mainly in the global south. Colonialism and its far-reaching consequences as well as religion became crucial 'intersections' of feminist theology of the 1970s. For this reason, the feminist theological 'interstructuring' was in fact not only earlier, but also broader and more global in its approach than intersectionality in the 1990s. By global, I here refer to feminist analyses in different geopolitical contexts and parts of the world, by local thinkers, but also to the explicit inclusion of an analysis of colonialism and global economic injustice as an essential part of feminist critique.

Connections to this global movement of liberation theologies influenced feminist theology especially as they were practised and theorised in the Ecumenical Association of the Third World Theologians (EATWOT) that was founded in 1976. It was a forum of Christian theologians from all over the world, which focused on changes not only in theology, but also in the churches and society. In the context of EATWOT, a global, feminist liberation theological paradigm was created, that included feminist theologians from Asia, Africa, Latin America, and the global north.

Different liberation theologies have influenced each other since the 1970s. Latin American liberation theologians were criticised for avoiding race and ethnicity issues. Black theologians were criticised for a lack of class analysis. Asian and African liberation theologians brought perspectives from multi-ethnic and multi-religious contexts. Most feminist theologians agree that the gender perspective - women, for them - was the last to be included in the liberation theological agenda. According to them, feminism needs to be understood broadly, not only as a struggle against sexism, but also 'against racism, classism, colonialism and militarism as structures of women's exploitation and oppression’ (Fiorenza 1989: 316). For most feminist theologians from the global south,

\footnotetext{
${ }^{13}$ Even though liberation theology has been a primarily Christian phenomenon, there are similar liberation theologies in other religious traditions, especially in Islam and Judaism.
} 
as well as for the womanist and mujerista theologians in the United States, this interstructuring of oppressions was their explicit starting point. ${ }^{14}$

A collection of Third World feminist theology from 1988 edited by Russell, Kwok, Isasi-Díaz and Cannon includes entries mostly from scholars who have their origins outside the United States, but have conducted their academic career there. Thus, there has been dialogue not only among white feminist, womanist, and mujerista theologians within the United States or liberation theologians of all sorts from various parts of the world, but also among theologians from racial and ethnic minorities in the USA and feminist theologians from the global south.

EATWOT was founded in 1976 in Dar-es-Salaam, Tanzania and regular global and regional conferences followed. ${ }^{15}$ EATWOT and its conferences have been crucial in the creation of not only liberation theology in the broad sense, but also of global feminist theology. In the reports of the first two conferences (Torres et al., eds. 1978; Appiah-Kubi et al., eds. 1979), women, sexism or feminism are not mentioned. It was only at the third conference of EATWOT in Sri Lanka in 1979 that the issue explicitly emerged (contributors to Fabella, ed. 1980; see especially, Katoppo 1980), and it has been on the agenda ever since.

At the conference of New Delhi in 1981, feminist theological issues gained force (contributors to Fabella et al., eds. 1983). One of the driving forces, Mercy Amba Oduyoye from Ghana termed the voice of feminists from the global south as the 'irruption within the irruption', referring to the theme of the New Delhi conference, which was Irruption of the Third World (Oduyoye 1983: 247). She writes:

Issues of sexism are supposed to belong to a minority of disgruntled, leisure-saturated, middle-class women of the capitalist West. (...) The fact is that sexism is part of the intricate web of oppression in which most of us live, and that having attuned ourselves to it does not make it any less a factor of oppression. Most Third World women, being literally close to the earth and to the maintenance of their race against classist and racist aggression, have opted to find complete fulfillment in this sacred duty and why not? But that does not mean an approval of sexism. (...) Feminism is anything but the imperialist ploy some would like us to take it for. (Oduyoye 1983: 249)

An important conference from the feminist theological perspective was that organised in Geneva in 1983 which focused on the dialogue between First World and Third World liberation theologians. ${ }^{16}$ (Fabella et al., eds. 1985). There had been earlier similar conferences in Detroit in 1975 and 1980, but they had concentrated on the Americas (Torres et al., eds. 1976).

A women's commission of EATWOT was created in 1983; after that, women held international and regional meetings. The first was held in Oaxtepec, Mexico in 1986, and the resulting book is the first compilation of feminist theological thinking from Africa, Asia, and Latin America (contributors to Fabella et al., eds. 1988; Ruether 2002: 14-18; see also contributors to King, ed. 1994). In the introduction to the book, which contains the papers held at the meeting, the editors state:

The context of poverty, multiple oppression, and tokenism shows up as a common experience of all the three continents. The Third World is a cross-ridden universe of economic, political, and religious-cultural oppressions within which women are doubly or triply burdened (Fabella et al. 1988: xi). ${ }^{17}$

Besides EATWOT, the ecumenical movement in general, especially the World Council of Churches (WCC) ${ }^{18}$ as well as interfaith organisations have been key factors in the early development of both feminist theology and liberation theology globally, including black theology in the USA, Africa, and Latin America. Detailed research on the subject has not yet been done, as far as I know (see however, King 1994: 8-12). According to Elisabeth Raiser:

The process of transforming the ecumenical community of churches into a truly 'inclusive' community gained momentum during the 1960s. Often ecumenical endeavours in this respect ran parallel to political

\footnotetext{
${ }^{14}$ See also the articles in Mission Trends 4 (1979), edited by G. H. Anderson and T. F. Stransky, on one of the early compilations of different forms of liberation theologies and critical dialogue between them, including feminist critique.

${ }^{15}$ Conferences have been held in Dar-es-Salaam, Tanzania (1976), Accra, Ghana (1977), Wennappuwa, Sri Lanka (1979), São Paulo, Brazil (1980), New Delhi, India (1981), Geneva, Switzerland (1983), Oaxtepec, Mexico (1986), Nairobi, Kenya (1992), Tagaytay, Philippines (1996), and Quito, Ecuador (2001).

${ }^{16}$ Feminist theologians such as Rosemary Ruether, Letty Russell, Elsa Tamez, Mercy Amba Oduyoye, and Dorothee Sölle were present.

17 The women's conference preceded the general assembly of EATWOT in Mexico in 1986. A collection on the commonalities and divergences between different forms of liberation theology, including feminist theology, brings together the papers presented at the general conference (Abraham, ed. 1990).

${ }_{18}$ The WCC is the largest and most encompassing formal organization of cooperation between Christian churches, although the Catholic Church is not a formal member.
} 
struggles for liberation and participation, and were inspired by the anti-apartheid and civil-rights movements, and not least by the emerging women's movement. (Raiser 2004: 243)

This demand for greater inclusivity did not occur without conflicts, and women's participation and critique became the touchstone of inclusivity in the ecumenical work. Tensions arose not only from the patriarchal structures of various member churches, but also in connection with different issues raised by women from the south and the north (Raiser 2004: 243-245). Thus, the WCC became one important forum for a global feminist dialogue, and it should not be overlooked: rather than focusing merely on the fact that this dialogue happened within and among Christian churches, it is important to acknowledge the transnational and global character of this specific history of dialogue between feminists. A department of Women in Church and Society was established within the WCC in 1971. Feminist theologians from the global south, such as Mercy Amba Oduyoye from Ghana and Aruna Gnanadason from India, became prominent ecumenical and international leaders. ${ }^{19}$

The processes within EATWOT and WCC were partly parallel and also influenced each other. As I have said earlier, this process should be studied in detail. However, at this point I would like to compare the ecumenical and interfaith process of global feminism to its secular counterpart within the United Nations. Sometimes the processes overlapped: participants in one may have also participated in the other. Especially for feminists from the global south, the two processes were not necessarily as separated from each other as for feminists from the north. The ecumenical and interfaith context provided women from the south with education (in form of scholarships to pursue doctoral studies in Europe or the USA), leadership skills and positions, funds, and an established platform for concrete cooperation and dialogue. ${ }^{20}$ Another global process, again partly parallel, that has been significant for various forms of feminist interpretations of religion, is that of interreligious consultations, dialogues, and organisations. Within them, the transnational dialogue of women from Christian churches expanded to dialogues between feminists from different religious traditions (see, e.g., Egnell 2006; Eck et al., eds. 1986).

These histories need to be researched and told. Not only because they de facto are part of the history of feminism and feminist theorising, but also because they reveal how the relationship between religion, women and feminism, is far from simplistic and monolithic. For many women, their religion is both a source of oppression and empowerment, and not to pay attention to both, is historically and conceptually inaccurate.

\section{CONCLUSION}

My article is an example of not only a critical re-reading of the history of feminist theorising, but also a critique of the epistemic habits of academic feminism and its relation to feminist knowledge production. Following Clare Hemmings' insistence on paying attention to the exclusionary aspect of the historical record of academic feminism, I have highlighted an excluded body of work, that of feminist studies of religion, especially global feminist theology.

I have argued that key concepts such as intersectionality have been theorised in feminist theology earlier than possibly in any other field of feminist research due to the close cooperation of feminist theologians with liberation theologians from the global south. I also presented sketches for a history of feminist theorising from a fresh perspective, that of ecumenical, interfaith, and global feminist dialogue.

As I said in the beginning, it is beyond the scope of this article to analyse how theories of intersectionality, since Crenshaw, have been received and developed in later feminist theology. A short survey of some general presentations of feminist theology and gender studies in religion, seems to suggest that intersectionality as a term has not been used (see, e.g., Beattie 2005; Clague 2005; Hawthorne 2005; King 2005). This may be a continuation of the meagreness of explicit dialogue between feminist theology and secular gender theories, which has also been pointed out by others (e.g., Eriksson 1995; Stenström et al. 2007; Tsokkinen 2008; Vuola 2002: 118-123; Vuola 2007). In a collection of feminist theological essays from 2014, intersectionality is mentioned but not elaborated on (Lipsett et al., eds. 2014). Schüssler Fiorenza discusses intersectionality briefly in her recent book (Fiorenza 2011: 7-11).

To conclude, I offer some further remarks on how the inclusion of religion would broaden our focus of intersectionality. It is both important and possible to treat religion intersectionally as a producer of 'difference' among women as well as to analyse religion as a cross-cutting element within other differences, identity categories

\footnotetext{
${ }^{19}$ Several of the feminist theologians writing in Russell et al., (eds.) 1988 recognise the influence of EATWOT, WCC and other ecumenical networks for them. Many of them have worked or been active in one or another ecumenical organisation. For a recent European perspective on similar developments, see Walton 2016, 289. The concrete financial and other type of support from the ecumenical movement for the education of feminist theologians from the global south should be researched. There are several women theologians from Africa, Asia, and Latin America who have been able to pursue their doctoral studies abroad because of scholarships granted to them by the WCC and other ecumenical organisations.

${ }^{20}$ The WCC has also been crucial in developing theological education and research in the global south, yet another area in need of further research.
} 
and power asymmetries. However, it is imperative to distinguish between different aspects of religion - the institutional, cultural, ethical, doctrinal, and spiritual - in order to avoid reducing any religious tradition to a single aspect. If the concept of intersectionality is used as a theoretical tool to create more dialogue between gender studies in religion and other fields of feminist theorising, it should be applied both internally and externally. By this I mean that internal power asymmetries related to gender, race, and ethnicity, should be analysed carefully within each religious tradition, including women's interpretations (both academic and lived) of them. Externally, religion as a category in all its aspects would be considered in intersectional analyses when relevant. I would claim that it is relevant in most - if not all - cultures.

A broad and inclusive understanding of religion as well as research with different methods is essential. Secular feminism in its critique and avoidance of religion, and feminist theology in its critique of religions, have concentrated on the formal, institutional aspects of religion. This is understandable and necessary, but it is not enough: women negotiate with their religious communities and identities in multiple ways (see for example contributors to Gemzöe et al., eds. 2016). The approach of lived religion (for example, Hall, ed. 1997; McGuire 2008; Orsi 2002) pays attention to religion and everyday life, gender, body, and materiality - that is, ordinary women's and men's ways of living and reflecting on their religiosity. The lived religion approach has been primarily developed within religious studies, not theology or anthropology. In my view, for a further development of the approach, more multidisciplinary research is needed, in order to understand the interplay of religious institutions, their teachings and ordinary people's interpretations of them.

It is essential that scholars pay attention to sexist interpretations and practices within religions, but this should be made in relation to women's religious and other agency. In intersectional analyses, this means seeing religion not only as a 'difference' between women (of different cultures and religions, and within a given religious tradition and society), but also seeing gender as an intersectional category in the study of religion. This makes it possible to understand religion as both a structure of power and a source of empowerment and positive identity (Vuola 2012a: 142-143; Vuola 2015b: 42-45).

For any feminist analysis, it is crucial that religious women are seen in terms of their agency, including their critical or non-traditional assessment of their religious traditions. It may be that theories of intersectionality prove to be the most fruitful ways to create more dialogue between the study of religion and feminist theorizing, minimising the, until now, too-narrow understanding of religion. Obviously, it means detailed analyses of religion and gender in different cultural, political, and social contexts, as well as in different religious traditions to avoid monolithic interpretations of the complex category of religion.

It remains to be seen if intersectionality as theorised primarily in the global north is a suitable framework also for feminist theorizing in the global south. The term has been used globally in development and human rights discourses and practices, but it is important to take into account of the fact that in spite of its history it is still a concept created in the global north, especially in the United States. It is clear that the inclusion of issues of race, class, and ethnicity in relation to gender has been effectively developed by feminists in the global south well before the term intersectionality was coined. The analytical logics behind intersectionality have been present in feminist theology and feminist critiques in the global south before it became a 'buzzword' in contemporary feminist theory. I myself have discussed the possibilities of the use of the term in the context of Latin America (Vuola 2012a), taking into account both religion and the specific intellectual history of the region. Whether these specific forms of feminist thinking are called intersectional or not is a matter of definition. The critical purchase lies in recognising and analysing different forms of oppression and how they overlap, and this insight is not dependent on whether this particular word is used or not.

The vast debate between universality and cultural relativism as it is related to gender issues and women's rights is still - or even increasingly - important for gender studies and feminism. It is central to any feminist project, theoretical or practical, to take into account that the potential dangers of cultural relativism or cultural essentialism are as important as the dangers of universalism. This issue is directly related to the ways we understand and use the concept of intersectionality. For example, according to Uma Narayan:

The project of attending to differences among women across a variety of national and cultural contexts becomes a project that endorses and replicates problematic and colonialist assumptions about the cultural differences between 'Western culture' and 'Non-western cultures' and the women who inhabit them. Seemingly universal essentialist generalizations about "all women" are replaced by culture-specific essentialist generalizations that depend on totalizing categories such as 'Western culture', 'Non-western cultures', 'Western women', 'Third World women', and so forth. (Narayan 2000, 81, emphasis in original)

For her, in a way that is similar to gender essentialism, cultural essentialism assumes and constructs sharp binaries, and in both cases, the discursive reiteration of essential differences often operates to conceal their role in the production and reproduction of such 'differences' (ibid.: 82). She emphasises the importance of paying attention to internal plurality, dissension, and contestation over values and ongoing changes within any category 
(nation, religion, gender, etc.) - which is not to deny the existence of differences per se (ibid.: 96). Narayan theorizes from within a postcolonial feminist context, which is why her critique has relevance not only to theories of intersectionality in general, but especially to feminist theorising in the global south.

The importance of my argument in this article lies in its contribution to the historiography and ways of exclusion in contemporary feminist theory. It is not only the aspect of religion and theology that I highlight, but also their global character, as expressed in feminist theological cooperation in ecumenical and transnational contexts. Looking forward, the importance of understanding feminist de- and re-constructions of religion in different cultural contexts lies in its potential to counter what I have called patriarchal ecumenism (Vuola 2009: 227-229). The growing cooperation and alliance among Catholic, Protestant, Orthodox, and Muslim conservative sectors on issues of sexuality, family, and gender, can be countered only with an adequate understanding of each religious tradition. A feminist critique and possible reinterpretation of religion from within those traditions is more credible and powerful than a secularist, anti-religious, feminist critique, which is easy to be dismissed because of its oftenunfortunate lack of acknowledgement of religion in general, and different religious traditions in particular. This recognition is especially crucial in societies in which hegemonic religions have (growing) influence on legislation. Even in Western Europe, it is more crucial than ever to be able to argue that feminism and religion are not necessarily and always opposing forces: that feminism does not equal secular and anti-religion. Politically, then, it is important to show how religion and feminism have positively interacted in different times and in different contexts, and that such a feminist critique of religion which is based on the ability to read and interpret its sacred texts, dogma, teachings, and symbolism, is possibly the best method to achieve such an understanding.

\section{REFERENCES}

Abraham, K.C. (ed.) (1990). Third World Theologies. Commonalities and Divergences. New York: Orbis Books.

Ahmed, L. (1992). Women and Gender in Islam. Historical Roots of a Modern Debate. New Haven: Yale University Press. Appelros, E. (2005). Religion och intersektionalitet. Kvinnovetenskaplig tidskrift, 2-3, pp. 69-80.

Appiah-Kubi, K. and Torres, S. (eds.) (1979). African Theology en Route. New York: Orbis Books.

Beattie, T. (2005). Feminist Theology: Christian Feminist Theology. In: L. Jones, ed. in chief, Encyclopedia of Religion (pp. 3034-3039). 2nd ed. Vol. 5. Detroit: Thomson Gale.

Brah, A. and Phoenix, A. (2004). Ain't I A Woman? Revisiting Intersectionality. Journal of International Women's Studies, 5(3), pp. 75-86.

Braidotti, R. (2008). In Spite of the Times. The Postsecular Turn in Feminism. Theory, Culture and Society, 25(6), pp. $1-24$.

Braude, A. (2001). Radical Spirits. Spiritualism and Women's Rights in Nineteenth-Century America. Second edition. Bloomington and Indianapolis: Indiana University Press.

Braude, A. (2004). Introduction. In: A. Braude, ed., Transforming the Faiths of Our Fathers. Women Who Changed American Religion (pp. 1-11). New York: Palgrave Mac Millan.

Braude, A. (ed.) (2004). Transforming the Faiths of Our Fathers. Women Who Changed American Religion. New York: Palgrave MacMillan.

Brekus, C.A. (2007). Introduction: Searching for Women in Narratives of American Religious History. In: C.A. Brekus, ed., The Religious History of American Women. Reimagining the Past (pp. 1-50). Chapel Hill: The University of North Carolina Press.

Cannon, K.G. (1988). Black Womanist Ethics. Atlanta: Scholars Press.

Casanova, J. (1994). Public Religions in the Modern World. Chicago: University of Chicago Press.

Castelli, E. (2001). Women, Gender, Religion: Troubling Categories and Transforming Knowledge. In: E. Castelli, ed., Women, Gender, Religion: A Reader (pp. 3-25). New York: Palgrave MacMillan.

Christ, C. and Plaskow, J. (eds.) (1979). Womanspirit Rising. A Feminist Reader in Religion. San Francisco: Harper \& Row.

Clague, J. (2005) Women's Studies in Religion. In: L. Jones, ed. in chief, Encyclopedia of Religion (pp. 9785-9796). 2nd ed. Vol. 14. Detroit: Thomson Gale.

Crenshaw, K. (1989). Demarginalizing the Intersection of Race and Sex. A Black Feminist Critique of Antidiscrimination Doctrine, Feminist Theory and Antiracist Politics. University of Chicago Legal Forum, pp. 139167.

Crenshaw, K. (1991). Mapping the Margins. Intersectionality, Identity Politics, and Violence against Women of Color. Stanford Law Review, 43(6), pp. 1241-1299.

Davis, K. (2008). Intersectionality as buzzword: A sociology of science perspective on what makes feminist theory successful. Feminist Theory, 9(1), pp. 67-85.

Donaldson, L. and Kwok P.-L. (eds.) (2002). Postcolonialism, Feminism, and Religious Discourse. New York: Routledge. 
Eck, D. and Jain, D. (eds.) (1986). Speaking of Faith. Cross-Cultural Perspectives on Women, Religion, and Social Change. London: The Women's Press.

Egnell, H. (2006). Other Voices. A Study of Christian Feminist Approaches to Religious Pluralism East and West. Uppsala: Swedish Institute of Mission Research.

Eriksson, A.-L. (1995). The Meaning of Gender in Theology: Problems and Possibilities. Stockholm: Almqvist och Wiksell International.

Fabella, V. (ed.) (1980). Asia's Struggle for Full Humanity. Towards a Relevant Theology. New York: Orbis Books.

Fabella, V. and Oduyoye, M.A. (1988). Introduction. In: V. Fabella and M.A. Oduyoye, eds., With Passion and Compassion. Third World Women Doing Theology (pp. ix-xv). New York: Orbis Books.

Fabella, V. and Oduyoye, M.A. (eds.) (1988). With Passion and Compassion. Third World Women Doing Theology. New York: Orbis Books.

Fabella, V. and Torres, S. (eds.) (1983). Irruption of the Third World. Challenge to Theology. New York: Orbis Books.

Fabella, V. and Torres, S. (eds.) (1985). Doing Theology in a Divided World. New York: Orbis Books.

Fiorenza, E. (1975). Feminist Theology as a Critical Theology of Liberation. Theological Studies, 36, pp. 605-626.

Fiorenza, E. (1989). The Politics of Otherness: Biblical Interpretation as a Critical Praxis of Liberation. In: M.H. Ellis and O. Maduro, eds., The Future of Liberation Theology. Essays in Honor of Gustavo Gutierrez. (pp. 311-325). Second edition. New York: Orbis Books.

Fiorenza, E. (2011). Transforming Vision. Explorations in Feminist The ${ }^{*} \log$. Minneapolis: Fortress Press.

Gemzöe, L., Keinänen, M.-L. and Maddrell, A. (eds.) (2016). Contemporary Encounters in Gender and Religion. European Perspectives. New York: Palgrave MacMillan.

Grant, J. (1989). White Women's Christ and Black Women's Jesus. Feminist Christology and Womanist Response. Atlanta: Scholars Press.

Halkes, C. and Buddingh, D. (eds.) (1979). Wenn Frauen ans Wort kommen. Stimmen zur feministischen Theologie. Berlin: Gelnhausen.

Hall, D. (ed.) (1997). Lived Religion in America. Toward a History of Practice. Princeton: Princeton University Press.

Hammar, I. (1998). Några reflexioner kring 'religionsblind' kvinnoforskning. Historisk tidskrift, 1.

Hammar, I. (2010). From Fredrika Bremer to Ellen Key: Calling, Gender and the Emancipation Debate in Sweden, c. 1830-1900. In: P. Markkola, ed., Gender and Vocation. Women, Religion and Social Change in the Nordic Countries, 1830-1940 (pp. 27-67). Helsinki: Finnish Literature Society.

Hawthorne, S. (2005). Feminism, Gender Studies, and Religion. In: L. Jones, ed. in chief, Encyclopedia of Religion (pp. 3023-3027). 2nd ed. Vol. 5. Detroit: Thomson Gale.

Hemmings, C. (2005). Telling Feminist Stories. Feminist Theory, 6(2), pp. 115-139.

Hemmings, C. (2011). Why Stories Matter. The Political Grammar of Feminist Theory. Durham \& London: Duke University Press.

Isasi-Díaz, A.M. and Tarango, Y. (1988). Hispanic Women. A Prophetic Voice in the Church. New York: Harper \& Row.

Katoppo, H. (1980). Asian Theology: An Asian Woman's Perspective. In V. Fabella, ed., Asia's Struggle for Full Humanity. Towards a Relevant Theology (pp. 140-151). New York: Orbis Books.

King, U. (1994). Introduction. In: U. King, ed., Feminist Theology from the Third World. A Reader (pp. 1-20). London and New York: SPCK and Orbis Books.

King, U. (2005). Gender and Religion: An Overview. In: L. Jones, ed. in chief, Encyclopedia of Religion (pp. 32963310). 2nd ed. Vol. 5. Detroit: Thomson Gale.

King, U. (ed.) (1994). Feminist Theology from the Third World. A Reader. London and New York: SPCK and Orbis Books.

Kinnunen, T. (2014). Alexandra Gripenberg's Feminist Christianity. In: T. Utriainen and P. Salmesvuori, eds., Finnish Women Making Religion. Between Ancestors and Angels (pp. 61-79). New York: Palgrave MacMillan.

Kwok, P-L. (2002). Feminist Theology as Intercultural Discourse. In: S.F. Parsons, ed., The Cambridge Companion to Feminist Theology (pp. 23-39). Cambridge: Cambridge University Press.

Lipsett, B.D. and Trible, P. (eds.) (2014). Faith and Feminism. Ecumenical Essays. Louisville: Westminster John Knox Press.

Ludvig, A. (2006). Differences between Women? Intersecting Voices in a Female Narrative. European Journal of Women's Studies, 13(3), pp. 245-258.

Lykke, N. (2003). Intersektionalitet - ett användbart begrepp för genusforskningen. Kvinnovetenskaplig tidskrift, 1, pp. 47-56.

Lykke, N. (2005). Nya perspektiv på intersektionalitet. Problem och möjligheter. Kvinnovetenskaplig tidskrift, 2-3, pp. 7-17.

Mahmood, S. (2005) Politics of Piety. The Islamic Revival and the Feminist Subject. Princeton: Princeton University Press.

McCall, L. (2005). The Complexity of Intersectionality. Signs, 3(30), pp. 1771-1800.

McGuire, M.B. (2008). Lived Religion. Faith and Practice in Everyday Life. New York: Oxford University Press. 
Narayan, U. (2000). Essence of Culture and a Sense of History: A Feminist Critique of Cultural Essentialism. In: U. Narayan and S. Harding, eds., Decentering the Center. Philosophy for a Multicultural, Postcolonial, and Feminist World (pp. 80-109). Bloomington: Indiana University Press.

Nash, J.C. (2008). Re-thinking intersectionality. Feminist Review, 89, pp. 1-15.

Oduyoye, A. (1983). Reflections from a Third World Woman's Perspective: Women's Experience and Liberation Theologies. In: V. Fabella and S. Torres, eds., Irruption of the Third World. Challenge to Theology (pp. 246-255). New York: Orbis Books.

Orsi, R.A. (2002). The Madonna of the 115th Street. Faith and Community in Italian Harlem, 1880-1950, 2nd ed. New Haven: Yale University Press.

Raiser, E. (2004). Inclusive Community. In: J. Briggs, M.A. Oduyoye and G. Tsetsis, eds., A History of the Ecumenical Movement, Vol. 3, 1968-2000 (pp. 243-277). Geneva: World Council of Churches.

Ruether, R. (1972). Liberation Theology. Human Hope Confronts Christian History and American Power. New York: Paulist Press.

Ruether, R. (1975). New Woman, New Earth. Sexist Ideologies and Human Liberation. San Francisco: Harper \& Row.

Ruether, R. (1982). Disputed Questions: On Being a Christian. Nashville: Abingdon.

Ruether, R. (2002). The Emergence of Christian Feminist Theology. In: S.F. Parsons, ed., The Cambridge Companion to Feminist Theology (pp. 3-22). Cambridge: Cambridge University Press.

Russell, L., Kwok P.-L, Isasi-Díaz A.M. and Cannon K.G. (eds.) (1988). Inheriting Our Mothers' Gardens. Feminist Theology in Third World Perspective. Louisville: The Westminster Press.

Stenström, H. and Vuola, E. (2007). Introduction. Journal of the European Society for Women in Theological Research 2007: Scandinavian Critique of Anglo-American Feminist Theology, pp. 3-13.

Torres, S. and J. Eagleson (eds.) (1976). Theology in the Americas. New York: Orbis Books.

Torres, S. and Fabella, V. (eds.) (1978). The Emergent Gospel. Theology from the Underside of History. New York: Orbis Books.

Tsokkinen, A. (2008). Etuoikeutettu sukupuoli? Käsitys auktoriteetista Elisabeth Schüssler Fiorenzan feministisessä teologiassa. Helsinki: Suomalainen Teologinen Kirjallisuusseura.

Vuola, E. (2002). Limits of Liberation. Feminist Theology and the Ethics of Poverty and Reproduction. Sheffield and New York: Sheffield Academic Press and Continuum.

Vuola, E. (2006). Seriously Harmful for Your Health? Religion, Feminism, and Sexuality in Latin America. In: M. Althaus-Reid, ed., Liberation Theology and Sexuality (pp. 137-162). Aldershot: Ashgate.

Vuola, E. (2007). Study of Religion and Feminist Theory: Dialogue or Silence? Journal of the European Society for Women in Theological Research 2007: Scandinavian Critique of Anglo-American Feminist Theology, pp. 189-197.

Vuola, E. (2009). Patriarchal Ecumenism, Feminism, and Women's Religious Experiences in Costa Rica. In: H. Herzog and A. Braude, eds., Gendering Religion and Politics. Untangling Modernities (pp. 217-238). New York: Palgrave MacMillan.

Vuola, E. (2012a). Intersectionality in Latin America? The Possibilities of Intersectional Analysis in Latin American Studies and Study of Religion. In: S. Lundgren, T. Machado-Borges and C. Widmark, eds., Bodies and Borders in Latin America (pp. 131-151). Stockholm: Stockholm University and University of Gothenburg.

Vuola, E. (2012b). La Morenita on Skis. Women's Popular Marian Piety and Feminist Research on Religion. In: M. McClintock Fulkerson and S. Briggs, eds., The Oxford Handbook of Feminist Theology (pp. 494-524). Oxford and New York: Oxford University Press.

Vuola, E. (2015a). The Exclusion of (the Study of) Religion in Latin American Gender Studies. LASA Forum, XLVI(1), 17-19. http://lasa.international.pitt.edu/forum/past-issues/vol46-issue1.asp

Vuola, E. (2015b). Unohdettu ero? Intersektionaalisuus, naiset ja uskonto. In: J. Ahonen and E. Vuola, eds., Uskonnon ja sukupuolen risteykesiä (pp. 32-54). Helsinki: Suomalaisen Kirjallisuuden Seura.

Vuola, E. (2016). Feminist Theology, Religious Studies and Gender Studies: Mutual Challenges. In: L. Gemzöe, M.-L. Keinänen and A. Maddrell, eds., Contemporary Encounters in Gender and Religion. European Perspectives (pp. 307-334). New York: Palgrave MacMillan.

Walker, Alice (1983). In Search of Our Mothers' Gardens: Womanist Prose. New York: Harcourt, Brace \& Jovanovich.

Walton, H. (2016). The History of Feminist Theology in the Academy: An Autoethnographic Research Journey. In: L. Gemzöe, M.-L. Keinänen and A. Maddrell, eds., Contemporary Encounters in Gender and Religion. European Perspectives (pp. 285-305). New York: Palgrave MacMillan.

Yuval-Davis, N. (2006). Intersectionality and Feminist Politics. European Journal of Women's Studies, 13(3), pp. 193209. 
Citation: Vuola, E. (2017). Religion, Intersectionality, and Epistemic Habits of Academic Feminism. Perspectives from Global Feminist Theology. Feminist Encounters: A Journal of Critical Studies in Culture and Politics, 1(1), 04. https://doi.org/10.20897/femenc.201704

Copyright (C) 2017 by Author/s and Licensed by Lectito BV, Netherlands. This is an open access article distributed under the Creative Commons Attribution License which permits unrestricted use, distribution, and reproduction in any medium, provided the original work is properly cited. 